Jurnal Ilmiah Farmasi 16(2) Agustus-Desember 2020, Hal.118-129

ISSN: $1693-8666$

available at http://journal.uii.ac.id/index.php/JIF

\title{
Assessment of physicochemical properties and comparison of the dissolution profile of amoxicillin caplets
}

\section{Uji sifat fisika-kimia dan disolusi terbandingkan kaplet amoksisilin}

\author{
Een Widiyasari ${ }^{1}$, Teuku Nanda Saifullah Sulaiman ${ }^{2 *}$ \\ 1 Program S-1 Fakultas Farmasi Universitas Gadjah Mada, Yogyakarta \\ ${ }^{2}$ Laboratorium Teknologi Farmasi, Departemen Farmasetika, Fakultas Farmasi Universitas Gadjah \\ Mada, Yogyakarta \\ *Corresponding author: tn_saifullah@ugm.ac.id
}

\begin{abstract}
Background: Marketed drugs must meet the required standards to guarantee product quality. Amoxicillin is a generic compound marketed under various trademarks as copy drugs. Amoxicillin caplets are an immediate release dosage form of BCS class I. An essential aspect of evaluating copy drugs is to assess the equivalence for their treatment to the innovator drugs to ensure the safety and effectiveness of the circulating copy drugs.

Objective: The study aims to evaluate the physicochemical properties and compare the dissolution profile of amoxicillin caplets available in the market.

Methods: Five amoxicillin caplet products, four test products, and one reference product were tested for their physicochemical properties and dissolution. The dissolution test was carried out with a type II device at a speed of $75 \mathrm{rpm}$ in $900 \mathrm{~mL}$ of media buffered at $\mathrm{pH} 1.2,4.5$, and 6.8 and at a temperature of $37^{\circ} \mathrm{C} \pm 0.5^{\circ} \mathrm{C}$. The dissolution profile was analyzed by comparing it with the similarity factor (f2) parameters.

Results: Two of the four amoxicillin caplet products had a similar dissolution profile to the reference products, namely products A and B.

Products $\mathrm{C}$ and $\mathrm{D}$ were dissimilar because $\mathrm{f} 2$ was $\leq 50$ at $\mathrm{pH} 4.5$. The caplets tested had almost the same dimensions, and all caplets met the requirements for uniformity of content, hardness, disintegration time, and dissolution.

Conclusion: Not all of the amoxicillin caplets in the market have a similar dissolution profile to the reference products.
\end{abstract}

Keywords: caplets, amoxicillin, dissolution, similarity factor

\section{Intisari}

Latar belakang: Sediaaan obat yang dipasarkan harus memenuhi standar yang ditetapkan untuk menjamin kualitas produk. Amoksisilin merupakan senyawa generik, dipasarkan dengan berbagai merek dagang yang merupakan obat copy. Kaplet amoksisilin merupakan sediaan dengan pelepasan segera yang termasuk dalam BCS kelas I. Komponen penting dalam mengevaluasi obat copy yaitu menilai kesetaraan terapinya terhadap obat inovator sehingga dapat menjamin bahwa obat copy yang beredar aman dan efektif.

Tujuan: Penelitian ini bertujuan untuk mengevaluasi sifat fisika kimia dan uji disolusi terbandingkan sediaan kaplet amoksisilin yang beredar dipasaran.

Metode: Sebanyak 5 produk kaplet amoksisilin, 4 produk uji dan 1 produk pembanding diuji sifat 
fisika kimia dan disolusinya. Uji disolusi dilakukan dengan alat tipe II dengan kecepatan 75 rpm dalam $900 \mathrm{~mL}$ media yang dibuffer pada $\mathrm{pH} 1,2 ; 4,5$; dan 6,8 dan suhu $37^{\circ} \mathrm{C} \pm 0,5^{\circ} \mathrm{C}$. Profil disolusi dianalisis dengan membandingkan profil disolusi dengan parameter similiarity factor $\left(\mathrm{f}_{2}\right)$.

Hasil: Hasil penelitian menunjukkan 2 produk dari 4 produk kaplet amoksisilin memiliki kemiripan profil disolusi terhadap produk pembanding yaitu produk A dan B, sementara 2 produk yang lain tidak memiliki kemiripan karena nilai $\mathrm{f} 2 \leq 50$ pada pH 4,5 (produk C dan D). Kaplet yang diuji memiliki dimensi yang hampir sama, semua kaplet memenuhi persyaratan keseragaman sediaan, kekerasan, waktu hancur dan disolusi.

Kesimpulan: Kaplet amoksisilin yang beredar tidak semuanya memiliki kemiripan profil disolusi dibandingkan produk pembanding.

Kata kunci : kaplet, amoksisilin, disolusi, similiarity factor

\section{Pendahuluan}

Produk obat bermerek dan produk obat generik memiliki zat aktif yang sama dengan inovatornya, hanya berbeda pada warna, bentuk, bahan tambahan, dan proses produksi yang khusus (Kesselheim et al., 2010). Banyak orang menilai kualitas obat tergantung pada harganya. Obat yang sudah disetujui untuk diedarkan, seharusnya memiliki kualitas yang setara. Obat dengan harga murah memiliki kualitas yang setara dengan obat dengan harga mahal (Arafat et al., 2017; Kesselheim et al., 2008).

Komponen penting dalam mengevaluasi obat generik adalah dengan menilai kesetaraan terapi obat menggunakan studi komparatif dengan pembanding yang sesuai, seperti studi bioekivalensi in vivo atau disolusi in vitro. Studi bioekivalensi in vivo rumit dan mahal. Disolusi in vitro digunakan sebagai alternatif untuk obat-obat terpilih (Thambavita et al., 2018).

Badan pengawas obat dan makanan berkewajiban melakukan pengawasan terhadap produk obat yang telah dipasarkan untuk memberikan jaminan kepada masyarakat bahwa produk obat telah memenuhi standar efikasi, keamanan dan mutu yang dibutuhkan. Untuk menjamin mutu obat copy yang beredar di Indonesia, perlu dilakukan uji bioekivalensi untuk membuktikan kesetaraannya terhadap produk inovatornya (BPOM, 2015). Dua produk obat dikatakan sama atau dua obat dapat diklaim bioekivalen, diasumsikan bahwa kedua obat akan memberikan efek terapi yang sama atau memiliki kesetaraan terapi (Chow, 2014).

Biowaiver perlu dilakukan untuk memperlihatkan bahwa obat dengan zat aktif dan bentuk sediaan yang sama memiliki kemiripan atau ekivalen antara produk yang satu dengan produk yang lain (Mhamunkar, 2013). Berdasarkan peraturan World Health Organization (WHO) mengenai biowaiver, obat yang termasuk kedalam BCS kelas I dan III memenuhi persyaratan untuk dinilai kesetaraan terapinya dengan menggunakan biowaiver (WHO, 2015). 
Biowaiver merupakan metodologi yang membutuhkan biaya yang lebih rendah untuk menilai kesetaraan obat generik terhadap inovatornya. Biowaiver dapat dilakukan terhadap produk obat dengan pelepasan segera (Reddy et al., 2014). Biowaiver dapat digunakan untuk menilai ekivalensi produk obat dengan kelarutan tinggi, tidak mengandung bahan tambahan yang mempengaruhi penyerapan zat aktifnya, tidak mengandung zat aktif dengan indeks terapi yang sempit, bukan obat yang dapat diabsorpsi di mulut (WHO, 2006).

Dari studi kelarutan dan permeabilitas menunjukkan bahwa amoksisilin dengan dosis kurang dari 875 mg masuk ke dalam BCS kelas I, sedangkan 875 mg hingga 1000 mg masuk ke dalam BCS kelas II, dan dosis lebih dari 1000 mg masuk ke dalam BCS kelas IV. Dalam penelitian ini digunakan kaplet 500 mg, sehingga termasuk dalam BCS kelas 1 . Dengan mempertimbangkan banyak aspek, prosedur biowaiver dapat direkomendasikan untuk produk sediaan oral padat dari amoksisilin dengan pelepasan segera dengan dosis kurang dari $875 \mathrm{mg}$ (Thambavita et al., 2017). Amoksisilin tidak termasuk dalam obat dengan indeks terapi yang sempit (Blix et al., 2010). Tablet amoksisilin bukan termasuk obat yang diabsorpsi di mulut. Tablet amoksisilin memenuhi persyaratan untuk dilakukan studi biowaiver (Thambavita et al., 2017). Penelitian ini bertujuan untuk mengevaluasi sifat fisika kimia dan uji disolusi terbandingkan sediaan kaplet amoksisilin yang beredar dipasaran dan kemungkinan untuk dilakukan studi biowaiver.

\section{Metodologi penelitian}

\subsection{Alat penelitian:}

Peralatan yang digunakan dalam penelitian: alat uji disintegrasi (Erweka ZT 320), alat uji disolusi (Erweka DT 820), hardness tester, Spektrofotometer UV (Hitachi U-2900), neraca analitik (Ohaus AX124), dan mikropipet (Booeco NF 996677).

\subsection{Bahan penelitian}

Bahan penelitian yang digunakan: kaplet amoksisilin $500 \mathrm{mg}$ sebagai produk pembanding (E), 2 jenis kaplet amoksisilin generik berlogo $500 \mathrm{mg}$ (A dan B), 2 jenis kaplet amoksisilin generik bermerek $500 \mathrm{mg}$ (C dan D), amoksisilin (working standart, USP), $\mathrm{HCl}$ 0,1 $\mathrm{N}$, dapar $\mathrm{HCl}(\mathrm{pH} 1,2)$, dapar asetat $(\mathrm{pH} 4,5)$, dapar fosfat $(\mathrm{pH} \mathrm{6,8)}$, akuades.

\subsection{Jalannya penelitian}

\section{i. Uji sifat fisik kaplet}

Uji sifat fisik yang diuji meliputi diameter dan ketebalan kaplet, uji kekerasan dan waktu hancur. Uji diameter dan ketebalan kaplet dilakukan dengan mengukur diameter dan ketebalan 
kaplet dengan jangka sorong (Kemenkes, 2014). Uji kekerasan dilakukan dengan menggunakan hardness tester. Kaplet diletakkan di ujung alat, skrup diputar sampai tablet pecah. Nilai kekerasan kaplet dibaca pada skala yang tertera pada alat dengan satuan kg (Kemenkes, 2014). Uji waktu hancur dilakukan dengan menggunakan disintegration tester. Setiap tabung dari keranjang diisi dengan satu kaplet, dimasukkan satu cakram pada tiap tabung dan dijalankan alat. Tablet dimasukkan ke dalam media air dengan suhu $37^{\circ} \mathrm{C} \pm 2^{\circ} \mathrm{C}$. Alat dijalankan hingga semua fraksi pecahan kaplet lewat ayakan yang terletak pada bagian bawah alat (Kemenkes, 2014).

\section{ii. Uji keseragaman sediaan}

Uji keseragaman sediaan dilakukan dengan cara menimbang secara saksama 10 tablet satu per satu. Ditetapkan jumlah zat aktif dalam tiap tablet yang dinyatakan dalam persen dan jumlah yang tertera pada etiket dari hasil Penetapan kadar masing-masing tablet, dihitung nilai penerimaan. Diambil 10 kaplet dari masing-masing produk, digerus hingga halus. Ditimbang sebanyak 100,0 mg serbuk kemudian dimasukkan kedalam labu takar $100 \mathrm{~mL}$, ditambahkan larutan $\mathrm{HCl}$ 0,1 $\mathrm{N}$ hingga tanda dan di homogenkan. Sampel diukur serapannya dengan menggunakan spektrofotometer pada panjang gelombang $228 \mathrm{~nm}$ (Kemenkes, 2014).

iii. Uji disolusi

Uji disolusi dilakukan dengan menggunakan alat tipe 2 USP. Pengaturan alat: putaran pengaduk pada $75 \mathrm{rpm}$, jumlah medium disolusi $900 \mathrm{~mL}$, dan suhu $37^{\circ} \mathrm{C}\left( \pm 0,5^{\circ} \mathrm{C}\right)$. Media yang digunakan yaitu larutan dapar $\mathrm{HCl} \mathrm{pH}$ 1,2; dapar asetat $\mathrm{pH} 4,5$; dapar fosfat $\mathrm{pH} 6,8$. Kaplet dimasukkan ke dalam bejana disolusi, alat dijalankan dan diambil sampel sebanyak $5 \mathrm{~mL}$ pada menit ke $10,15,20,30,45,60$. Setiap pengambilan larutan, diganti dengan medium dan suhu yang sama sebanyak $5 \mathrm{~mL}$. Kadar dihitung dengan menggunakan persamaan kurva baku yang telah diperoleh untuk masing-masing medium disolusi (BPOM, 2015).

iv. Pembuatan kurva baku amoksisilin untuk penetapan kadar dalam tablet dan dalam media disolusi

Kurva baku dibuat sebanyak 4 buah, yaitu: 1 untuk penetapan kadar dalam tablet dan 3 untuk penetapan kadar dalam berbagai media disolusi. Larutan stok dibuat dengan cara: 10,0 mg amoksisilin ditimbang secara seksama, dimasukkan ke dalam labu takar 10,0 mL dan ditambahkan berbagai larutan sesuai dengan tujuan penggunaan sampai tanda. Larutan yang ditambahkan yaitu $\mathrm{HCl}$ 0,1 N (untuk penetapan kadar); larutan $\mathrm{HCl} \mathrm{pH} \mathrm{1,2;} \mathrm{dapar} \mathrm{asetat} \mathrm{pH}$ 4,5 atau fosfat pH 6,8 (untuk uji penetapan kadar dalam media disolusi). Dibuat lima seri kadar dari 
masing-masing larutan stok tersebut. Sampel diukur serapannya dengan menggunakan spektrofotometer UV pada panjang gelombang maksimum (Gandjar \& Rohman, 2012).

\section{Hasil dan pembahasan}

\subsection{Sifat fisik kaplet dan penetapan kadar}

\subsubsection{Panjang, lebar dan ketebalan kaplet}

Pengukuran panjang, lebar dan ketebalan kaplet yang dilakukan mendapatkan hasil seperti yang tertera pada Tabel 1 .

Tabel 1. Hasil pengukuran dimensi kaplet amoksisilin

\begin{tabular}{lccccc}
\hline & \multicolumn{5}{c}{ Produk amoksisilin } \\
\cline { 2 - 6 } & $\mathrm{A}$ & $\mathrm{B}$ & $\mathrm{C}$ & $\mathrm{D}$ & $\mathrm{E}$ \\
\hline $\begin{array}{l}\text { Panjang } \\
\text { (mm) }\end{array}$ & $18,02 \pm 0,03$ & $18,05 \pm 0,06$ & $18,09 \pm 0,09$ & $17,25 \pm 0,03$ & $18,04 \pm 0,07$ \\
Lebar (mm) & $6,52 \pm 0,03$ & $6,99 \pm 0,04$ & $7,05 \pm 0,0$ & $5,93 \pm 0,03$ & $6,55 \pm 0,0$ \\
Tinggi (mm) & $5,89 \pm 0,08$ & $5,78 \pm 0,03$ & $5,93 \pm 0,03$ & $6,08 \pm 0,05$ & $5,92 \pm 0,03$ \\
\hline
\end{tabular}

Keterangan :

Nilai dalam $\bar{x} \pm$ SD; semua parameter memiliki nilai $\mathrm{CV}<5 \%$

A : Amoksisilin generik berlogo D : Amoksisilin generik bermerek

B : Amoksisilin generik berlogo E : Amoksisilin Pembanding

C : Amoksisilin generik bermerek

Tabel 1 menunjukkan ukuran kaplet yang seragam antara kaplet satu dengan kaplet lain, dengan nilai Coefficient Variasi (CV) < 5\% untuk semua parameter. Secara umum, sediaan yang diproduksi dengan bobot yang relatif sama akan menggunakan punch dan dies yang sama ukurannya. Dimensi kaplet yang relatif sama akan lebih mudah dalam membandingkan profil disolusi karena luas kontak awal pada saat disolusi akan sama.

\subsubsection{Keseragaman sediaan}

Keseragaman sediaan ditetapkan dengan salah satu dari dua metode, yaitu keragaman bobot dan keseragaman kandungan. Dalam hal ini dilakukan keragaman bobot karena zat aktif dalam tiap kaplet lebih dari 25\%. Hasil uji keragaman bobot kaplet diperoleh hasil yang tertera pada Tabel 2. Tabel II menunjukkan bahwa seluruh kaplet memenuhi persyaratan keragaman bobot kaplet $(\mathrm{NP}<15)$. Keragaman bobot yang baik memberikan jaminan bahwa kadar obat dalam setiap sediaan seragam. 
Tabel 2. Keseragaman sediaan kaplet amoksisilin

\begin{tabular}{ccccc}
\hline Produk & Bobot Kaplet(mg) & \multicolumn{3}{c}{ Label klim kadar (\%) } \\
& $\overline{\mathrm{x}} \pm \mathrm{SD}$ & $\overline{\mathrm{x}} \pm \mathrm{SD}$ & $\mathrm{NP}$ & $\mathrm{CV}$ \\
\hline $\mathrm{A}$ & $689,57 \pm 17,71$ & $98,51 \pm 2,53$ & 6,07 & 2,57 \\
$\mathrm{~B}$ & $661,01 \pm 12,18$ & $94,43 \pm 1,74$ & 8,25 & 1,84 \\
$\mathrm{C}$ & $660,09 \pm 13,42$ & $94,29 \pm 1,92$ & 8,80 & 2,03 \\
$\mathrm{D}$ & $692,13 \pm 9,13$ & $98,88 \pm 1,30$ & 3,13 & 1,32 \\
E & $693,11 \pm 7,31$ & $99,02 \pm 1,05$ & 2,51 & 1,06 \\
\hline Keterangan : & & & \\
A : Amoksisilin generik berlogo & $\mathrm{D}:$ Amoksisilin generik bermerek \\
B : Amoksisilin generik berlogo & $\mathrm{E}:$ Amoksisilin Pembanding \\
C : Amoksisilin generik bermerek & \multicolumn{3}{l}{}
\end{tabular}

\subsubsection{Kekerasan kaplet, waktu hancur dan penetapan kadar}

Pengukuran kekerasan, waktu hancur dan kadar dalam sediaan kaplet diperoleh hasil seperti yang tertera pada tabel 3 .

Tabel 3. Hasil uji kekerasan, waktu hancur dan penetapan kadar sediaan kaplet amoksisilin

\begin{tabular}{|c|c|c|c|c|c|}
\hline \multirow{2}{*}{$\begin{array}{l}\text { Parameter } \\
\text { uji }\end{array}$} & \multicolumn{5}{|c|}{ Kaplet } \\
\hline & A & B & $\mathbf{C}$ & D & $\mathbf{E}$ \\
\hline \multicolumn{6}{|c|}{ Kekerasan ( kg/cm2 ) } \\
\hline$\overline{\mathrm{x}} \pm \mathrm{SD}$ & $11,77 \pm 4,36$ & $4,28 \pm 1,06$ & $14,02 \pm 1,08$ & $8,99 \pm 2,18$ & $14,45 \pm 0,59$ \\
\hline CV (\%) & 37,08 & 24,73 & 7,72 & 24,3 & 4,05 \\
\hline \multicolumn{6}{|c|}{ Waktu Hancur (Menit) } \\
\hline$\overline{\mathrm{x}}$ & $3: 46$ & $2: 23$ & $5: 12$ & $2: 11$ & $3: 16$ \\
\hline \multicolumn{6}{|c|}{ Kadar Amoksisilin dalam kaplet (\%) } \\
\hline$\overline{\mathrm{x}} \pm \mathrm{SD}$ & $114,33 \pm 1,17$ & $104,42 \pm 4,07$ & $105,88 \pm 2,45$ & $113,29 \pm 2,57$ & $114,55 \pm 1,45$ \\
\hline CV $(\%)$ & 1,02 & 3,89 & 2,31 & 2,27 & 1,27 \\
\hline
\end{tabular}

\section{Keterangan :}

A : Amoksisilin generik berlogo $\quad$ D : Amoksisilin generik bermerek

B : Amoksisilin generik berlogo

E : Amoksisilin Pembanding

$\mathrm{C}$ : Amoksisilin generik bermerek

Hasil uji kekerasan kaplet, memiliki nilai kekerasan yang beragam yaitu $4-15 \mathrm{~kg} / \mathrm{cm}^{2}$. Kekerasan tablet yang beragam akan mempengaruhi waktu hancur dan disolusi. Data hasil uji waktu hancur juga menunjukkan waktu hancur yang beragam. Dari hasil tersebut terlihat tidak ada korelasi yang linear antara kekerasan dengan waktu hancur. Kekerasan yang tinggi tidak serta merta menyebabkan waktu hancur menjadi lebih lama, karena waktu hancur juga 
dipengaruhi oleh faktor lain seperti fungsi dan kinerja bahan penghancur, porositas tablet dan kemudahan penetrasi air. Semua tablet memenuhi persyaratan waktu hancur kurang dari 15 menit (Kemenkes, 2014).

Persyaratan kadar amoksisilin dalam kaplet: mengandung amoksisilin tidak kurang dari 90,0\% dan tidak lebih dari 120,0\% dari jumlah yang tertera pada etiket (Kemenkes, 2014). Kadar yang diperoleh terhadap 5 jenis kaplet menunjukkan bahwa semuanya memenuhi persyaratan. Dari nilai CV yang diperoleh, kadar amoksisilin dalam sediaan juga seragam .

\subsubsection{Kurva Baku Amoksisilin untuk Penetapan Kadar dalam kaplet dan Uji Disolusi}

Persamaan kurva baku amoksisilin dalam tercantum pada tabel 4.

Tabel 4. Persamaan kurva baku amoksisilin dalam berbagai media

\begin{tabular}{lllll}
\hline Pelarut/Medium & $\lambda$ max & Persamaan Kurva Baku & $\mathbf{R}$ & $\mathbf{r}^{2}$ \\
\hline HCl 0,1 N & 228 & $\mathrm{y}=0,0223 \mathrm{x}-0,0292$ & 0,99935 & 0,99967 \\
Dapar HCl pH 1,2 & 228 & $\mathrm{y}=0,022 \mathrm{x}-0,0762$ & 0,99820 & 0,99910 \\
Dapar Asetat pH 4,5 & 228 & $\mathrm{y}=0,0217 \mathrm{x}-0,0496$ & 0,99959 & 0,99979 \\
Dapar Fosfat pH 6,8 & 227 & $\mathrm{y}=0,0218 \mathrm{x}-0,0662$ & 0,99975 & 0,99987 \\
\hline
\end{tabular}

Persamaan kurva baku yang diperoleh mempunyai hubungan linier yang, sehingga dapat digunakan untuk penetapan kadar amoksisilin dalam kaplet maupun untuk uji disolusi. Hal ini ditunjukkan dengan nilai koefisien korelasi untuk ke-4 pelarut $>0,99$. Persyaratan harga $\mathrm{r}^{2}$ untuk metode pengukuran dengan spektrofotometri UV menurut USP 38 yaitu $\geq 0,98$ (USP, 2015).

\subsubsection{Profil disolusi dan disolusi terbanding}

Hasil uji disolusi amoksisilin dalam medium pH 1,2; 4,5 dan 6,8 ditunjukkan pada tabel 5. Hasil uji disolusi, dalam waktu 30 menit $100 \%$ obat sudah terdisolusi. Kaplet amoksisilin di dalam monografi (FI V), dipersyaratkan $\mathrm{Q}_{30}$ tidak kurang dari $75 \%$ terdisolusi dari yang tertera di etiket. Hasil interpretasi diperoleh hasil uji disolusi memenuhi persyaratan FI, yaitu untuk stage 1 (S1) maka dipersyaratkan tiap unit sediaan tidak kurang dari Q $+5 \%$ dan rata-rata jumlah zat terlarut tidak kurang dari Q + 10\% (Kemenkes, 2014). Amoksisilin trihidrat memiliki kelarutan dalam air 1 : 400, dan WHO juga mengklasifikasikan amoksisilin 250 dan 500 mg termasuk ke dalam BCS kelas I (kelarutan dan permeabilitas tinggi). Hal ini yang menyebabkan kaplet dapat terdisolusi dengan cepat, dalam waktu 20 menit sudah terdisolusi $100 \%$. 
Tabel 5. Persen rata-rata obat terdisolusi pada berbagai media

\begin{tabular}{|c|c|c|c|c|c|c|c|c|}
\hline \multicolumn{9}{|c|}{ Persen rata-rata obat terdisolusi $(Q)$ dalam buffer $\mathrm{HCl}$ pH 1,2 } \\
\hline \multirow[b]{2}{*}{ Kaplet } & & \multicolumn{7}{|c|}{ Waktu (menit) } \\
\hline & & 0 & 10 & 15 & 20 & 30 & 45 & 60 \\
\hline $\bar{A}$ & & 0 & 93,82 & 98,02 & 104,76 & 108,36 & 110,33 & 113,58 \\
\hline B & & 0 & 102,58 & 104,38 & 104,92 & 106,39 & 107,81 & 110,16 \\
\hline $\mathrm{C}$ & & 0 & 106,94 & 109,18 & 110,47 & 110,99 & 112,11 & 113,23 \\
\hline $\mathrm{D}$ & & 0 & 102,22 & 105,15 & 107,09 & 108,32 & 109,83 & 112,86 \\
\hline $\mathrm{E}$ & & 0 & 104,1 & 107,09 & 108,48 & 109,22 & 110,28 & 112,51 \\
\hline \multicolumn{9}{|c|}{ Persen rata-rata obat terdisolusi (Q) dalam buffer asetat $\mathrm{pH} 4,5$} \\
\hline \multicolumn{9}{|c|}{ Waktu (menit) } \\
\hline Kaplet & 0 & 10 & & 15 & 20 & 30 & 45 & 60 \\
\hline A & 0 & 81,26 & & 93,87 & 98,34 & 102,92 & 105,91 & 108,17 \\
\hline B & 0 & 84,57 & & 95,37 & 98,92 & 100,52 & 103,16 & 107,01 \\
\hline $\mathrm{C}$ & 0 & 94,04 & & 101,47 & 106,64 & 108,69 & 112,48 & 116,43 \\
\hline D & 0 & 88,29 & & 97,71 & 100,32 & 104,62 & 106,93 & 110,8 \\
\hline E & 0 & 75,27 & & $84,93^{*}$ & 89,5 & 93,5 & 97,37 & 103,43 \\
\hline
\end{tabular}

Persen rata-rata obat terdisolusi (Q) dalam buffer fosfat $\mathrm{pH} 6,8$

\begin{tabular}{|c|c|c|c|c|c|c|}
\hline \multirow[b]{2}{*}{ Kaplet } & \multicolumn{6}{|c|}{ Waktu (menit) } \\
\hline & $\begin{array}{ll}0 & 10\end{array}$ & 15 & 20 & 30 & 45 & 60 \\
\hline A & $0 \quad 92,98$ & 100,37 & 102,63 & 105,63 & 106,89 & 109,71 \\
\hline B & 90,57 & 95,18 & 100,12 & 103,83 & 105,1 & 106,5 \\
\hline $\mathrm{C}$ & 99,29 & 103,5 & 105,41 & 107,41 & 109,4 & 110,31 \\
\hline $\mathrm{D}$ & 95,56 & 105,43 & 109,36 & 110,85 & 112,27 & 113,7 \\
\hline $\bar{E}$ & 90,79 & 97,56 & 102,68 & 106,62 & 108,77 & 110,16 \\
\hline
\end{tabular}

\section{Keterangan :}

A : Amoksisilin generik berlogo $\quad$ D : Amoksisilin generik bermerek

B : Amoksisilin generik berlogo $\quad$ E : Amoksisilin Pembanding

$\mathrm{C}:$ Amoksisilin generik bermerek

$*: \mathrm{Q}<85 \%$

Persyaratan suatu kaplet dapat menyederhanakan uji bioekivalensi dengan studi biowaiver yaitu apabila produk uji terdisolusi $\geq 85 \%$ pada menit ke 15 . Produk uji yang memenuhi kriteria $\geq 85 \%$ obat terdisolusi pada menit ke 15 yaitu kaplet $A, B, C$, dan $D$ sedangkan kaplet C tidak memenuhi kriteria. Dalam kasus ini, biowaiver belum dapat dipertimbangkan untuk meniadakan uji invivo (Bioekivalen). Walaupun menurut Thambavita dkk., 2017, sediaan oral padat dari amoksisilin dengan pelepasan segera dengan dosis kurang dari 875 mg relevan untuk dilakukan biowaiver saja. 
Kurva profil disolusi kaplet amoksisilin dalam berbagai medium disolusi ditunjukkan pada gambar 1,2 dan3.

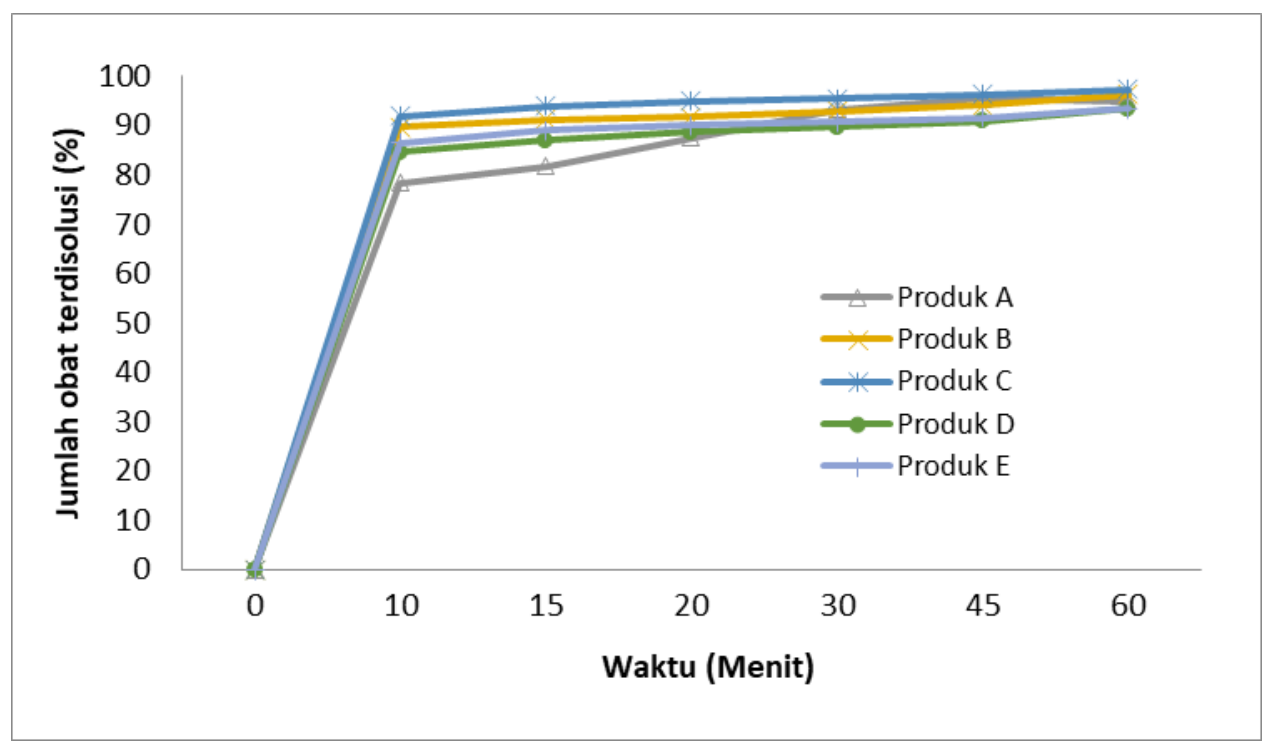

Gambar 1. Profil jumlah amoksisilin terdisolusi pada pH 1,2

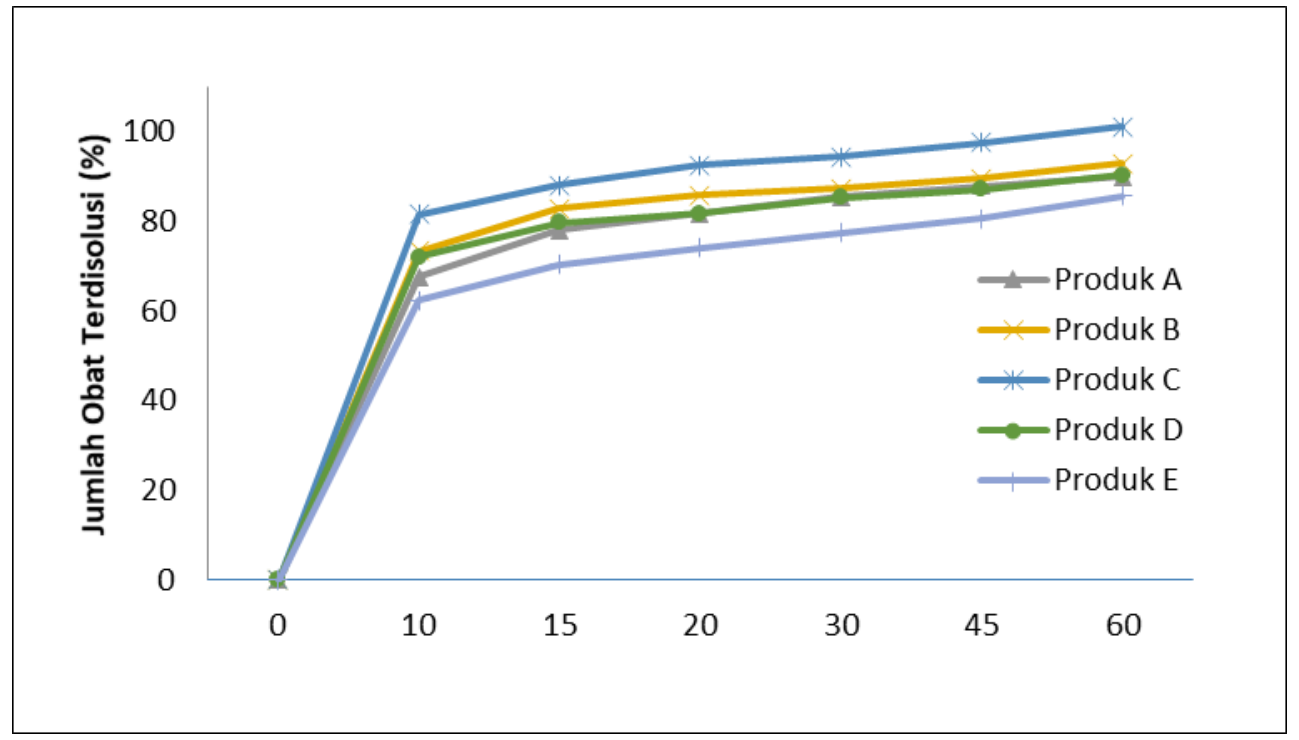

Gambar 2. Profil jumlah amoksisilin terdisolusi pada $\mathrm{pH} 4,5$ 


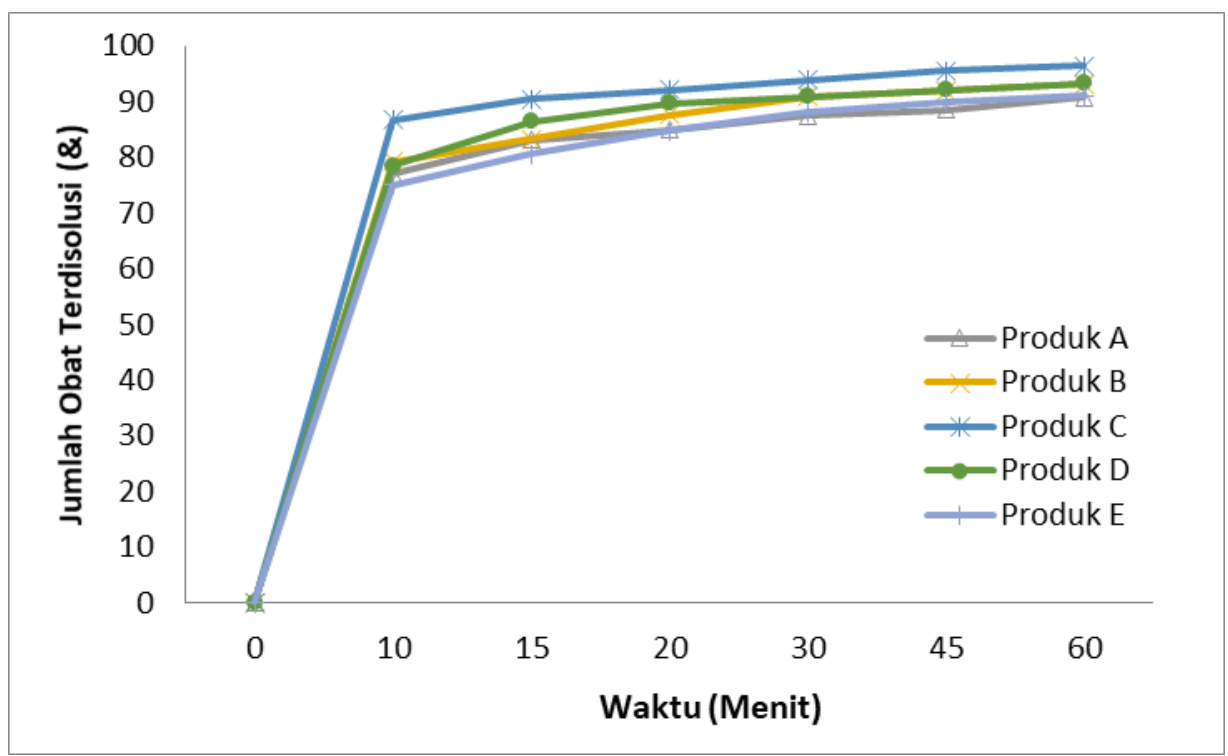

Gambar 3. Profil jumlah amoksisilin terdisolusi pada pH 6,8

Jumlah obat yang terdisolusi dari menit ke-0 hingga menit ke-10 naik dengan cepat karena kaplet yang diuji merupakan sediaan immediate release. Kaplet amoksisilin dengan kekuatan kurang dari 875 mg masuk ke dalam BCS kelas I, sehingga dalam waktu 10 menit 90 \% obat sudah terdisolusi. Kaplet dengan cepat terdisintegrasi yang diikuti dengan disolusi. Pada menit selanjutnya peningkatan jumlah obat yang terdisolusi menjadi perlahan karena jumlah obat yang belum terdisolusi tersisa sedikit.

Tabel 6. Nilai similaritas $\left(\mathrm{f}_{2}\right)$ berbagai produk kaplet amoksisilin

\begin{tabular}{clll}
\hline \multirow{2}{*}{$\begin{array}{c}\text { Perbandingan } \\
\text { Produk }\end{array}$} & \multicolumn{3}{c}{ Nilai $\mathbf{f}_{2}$} \\
\cline { 2 - 4 } & $\mathbf{p H ~ 1 , 2}$ & $\mathbf{p H ~ 4 , 5}$ & $\mathbf{p H ~ 6 , 8}$ \\
\hline A-E & 63,04 & 56,48 & 86,44 \\
B-E & 78,88 & 56,44 & 77,87 \\
C-E & 84,05 & $41,33^{*}$ & 68,89 \\
D-E & 90,11 & $49,60^{*}$ & 64,81 \\
B-C & 67,70 & 52,01 & 60,37 \\
\hline
\end{tabular}

Keterangan :

A : Amoksisilin generik berlogo

$B$ : Amoksisilin generik berlogo

C : Amoksisilin generik bermerek
D : Amoksisilin generik bermerek

E : Amoksisilin Pembanding

$*$ : Nilai $f_{2} \leq 50$ 
Uji disolusi terbanding dilakukan untuk membandingkan profil disolusi antara produk uji dengan produk pembanding. Produk uji dikatakan mirip dengan produk pembanding apabila memiliki nilai $\mathrm{f}_{2}$ (similiarity factor) $\geq 50$. Perbandingan profil disolusi juga dilakukan terhadap kaplet $\mathrm{B}$ dan $\mathrm{C}$ yang berasal dari industri yang sama. Nilai $\mathrm{f}_{2}$ dalam medium $\mathrm{pH} 1,2$; 4,5 dan 6,8 dari kaplet uji ditunjukkan pada tabel 6 .

Pada tabel 6 terlihat bahwa pada pH 1,2 dan 6,8 kaplet A, B, C, D memiliki nilai f2 $\geq 50$ dibandingkan dengan produk pembanding (kaplet E). Keempat kaplet memenuhi syarat uji disolusi terbandingkan (UDT) atau dengan kata lain tablet uji identik dengan kaplet pembanding (produk E). Pada pH 4,5 terdapat 2 produk uji yaitu kaplet $\mathrm{C}$ dan D memiliki nilai f2 kurang dari 50 sehingga tidak memiliki kemiripan dengan produk pembanding. Dapat disimpulkan bahwa hanya produk A dan B saja yang memenuhi syarat uji disolusi terbandingkan (sebanding dengan produk pembanding).

Dari uji disolusi yang dilakukan, hasil yang diperoleh dicoba korelasikan dengan hasil uji kekerasan dan waktu hancur kaplet. Umumnya kaplet dengan kekerasan yang tinggi akan memiliki waktu hancur dan disolusi yang lama. Akan tetapi, hasil yang diperoleh tidak demikian. Produk A, C, D, dan E memiliki kekerasan yang relatif cukup tinggi namun tetap memiliki waktu hancur yang cepat. Dari ke empat produk, waktu hancur terlama yaitu produk C yaitu 5 menit 12 detik, sementara produk B memiliki kekerasan 4,28 $\pm 1,06$, waktu hancurnya 2 menit 23 detik. Dari data uji disolusi pada ketiga $\mathrm{pH}$, semua produk mengalami peningkatan

disolusi secara cepat pada 10 menit pertama, sehingga disini kekerasan kaplet tidak berbanding lurus dengan kecepatan disolusi obatnya. Hal ini dapat disebabkan formula yang digunakan mengandung bahan yang dapat mempercepat waktu hancur dan kecepatan disolusinya.

\section{Kesimpulan}

Hasil uji sifat fisik kaplet, semua produk kaplet memiliki dimensi yang hampir sama, semua produk memenuhi persyaratan keseragaman sediaan, kekerasan, waktu hancur dan disolusi. Dari hasil disolusi, kaplet A dan B memiliki kemiripan profil disolusi terhadap obat pembanding (produk E) yang ditunjukkan dengan nilai $\mathrm{f}_{2} \geq 50$. Kaplet $\mathrm{C}$ dan $\mathrm{D}$ memiliki nilai $\mathrm{f}_{2}$ $\geq 50$ hanya pada pH 1,2 dan 6,8; sementara pada $\mathrm{pH} 4,5$ nilai $\mathrm{f} 2 \leq 50$ sehingga tidak memiliki kemiripan profil disolusi. 


\section{Daftar pustaka}

Arafat, A. P. D. M., Ahmed, Z., \& Arafat, O. (2017). Comparison between generic drugs and brand name drugs from bioequivalence and thermoequivalence prospective International Journal of Pharmacy and Pharmaceutical Sciences, 9, 1-4. doi:10.22159/ijpps.2017v9i6.18735

Blix, H. S., Viktil, K. K., Moger, T. A., \& Reikvam, A. (2010). Drugs with narrow therapeutic index as indicators in the risk management of hospitalised patients. Pharm Pract (Granada), 8(1), 50-55. doi:10.4321/s1886-36552010000100006

BPOM. (2015). Pedoman uji bioekivalensi. Jakarta: BPOM

Chow, S. C. (2014). Bioavailability and Bioequivalence in Drug Development. Wiley Interdiscip Rev Comput Stat, 6(4), 304-312. doi:10.1002/wics.1310

Gandjar, I. G., \& Rohman, A. (2012). Analisis obat secara spektrofotometri dan kromatografi. Yogyakarta: Pustaka Pelajar.

Kemenkes. (2014). Farmakope Indonesia. Jakarta: Kemenkes RI

Kesselheim, A. S., Misono, A. S., Lee, J. L., Stedman, M. R., Brookhart, M. A., Choudhry, N. K., \& Shrank, W. H. (2008). Clinical equivalence of generic and brand-name drugs used in cardiovascular disease: a systematic review and meta-analysis. JAMA, 300(21), 25142526. doi:10.1001/jama.2008.758

Kesselheim, A. S., Stedman, M. R., Bubrick, E. J., Gagne, J. J., Misono, A. S., Lee, J. L., Brookhart, M. A., Avorn, J., \& Shrank, W. H. (2010). Seizure outcomes following the use of generic versus brand-name antiepileptic drugs: a systematic review and meta-analysis. Drugs, 70(5), 605-621. doi:10.2165/10898530-000000000-00000

Mhamunkar, S. (2013). Comparative dissolution studies of an extended release Formulation of Tolterodine Tartrate and Tamsulosin HCl. BioMedRx, 1, 333-338.

Reddy, N. H., Patnala, S., Löbenberg, R., \& Kanfer, I. (2014). In vitro dissolution of generic immediate-release solid oral dosage forms containing BCS class I drugs: comparative assessment of metronidazole, zidovudine, and amoxicillin versus relevant comparator pharmaceutical products in South Africa and India. AAPS PharmSciTech, 15(5), 10761086. doi:10.1208/s12249-014-0135-6

Thambavita, D., Fernando, S., Galappaththy, P., \& Jayakody, R. (2018). Application of Biowaiver Methodology for a Post-Marketing Study of Generic and Brand Name Metronidazole Tablets. Dissolution Technologies, 25, 34-38. doi:10.14227/DT250218P34

Thambavita, D., Galappatthy, P., Mannapperuma, U., Jayakody, L., Cristofoletti, R., Abrahamsson, B., Groot, D. W., Langguth, P., Mehta, M., Parr, A., Polli, J. E., Shah, V. P., \& Dressman, J. (2017). Biowaiver Monograph for Immediate-Release Solid Oral Dosage Forms: Amoxicillin Trihydrate. J Pharm Sci, 106(10), 2930-2945. doi:10.1016/j.xphs.2017.04.068

USP. (2015). US Pharmacopeia National Formulary: USP 38/NF 33. Rockville: United States harmacopeia Inc.

WHO. (2006). WHO expert committee on specification for pharmaceutical preparations, 40th In. Geneva: WHO.

WHO. (2015). WHO expert committee on specification for pharmaceutical preparations, 49th In. Geneva: WHO. 